\title{
公共賃貸住宅居住世帯の住まい方と最低居住水準に規定された 住まい方の乘離について \\ DIFFERENCES BETWEEN THE CRITERIA OF MINIMUM HOUSING STANDARD AND THE PRACTICAL WAY OF DWELLING OF HOUSEHOLDS IN PUBLIC HOUSING
}

\author{
古田健 -*, 竹下輝 和**, 中園真人*** \\ Ken-ichi FURUTA, Terukazu TAKESHITA and Mahito NAKAZONO
}

\begin{abstract}
In minimum housing standard which has been established by the Ministry of Construction, the criteria for necessary area space of dwelling rooms per household are set up. The purpose of this paper is to clear up differences between the criteria and the practical way of dwelling of households in public housing. We examined original data of public housing in Fukuoka prefecture (1980). The results provide evidence that the size of a bed-room for two or more persons in smaller than the criteria's. This means that households use the largest rooms for living-rooms, diningrooms, etc. not for bed-rooms.
\end{abstract}

Keywords : housing standard, public housing, way of dwelling 居住水準, 公共住宅，住まい方

\section{1.はじめに}

第 3 期住宅建設 5 力年計画において政策決定された居 住水準の達成課題は，住宅政策を量から質へと転換する 上においてきわめて重要な意味を持つものであった。特 に公共賃貸住宅では，設定された居住水準に対応する規 模の住宅が $3 \mathrm{DK}$ を中心として供給され始め, 全国の平 均的な住户規模はしだいに拡大された。これにより，近 年では, $3 \mathrm{LDK} ゃ 4 \mathrm{LDK}$ 住戸の住まい方が議論される に至った刘ー3)。しかし一方では，いまだに最低居住水 準未満世帯が総世帯数の約 1 割存在し，早急にその解消 が望まれているほ1。

この最低居住水準には住まい方調査の結果を基に，食 寝分離・就寝分離をすべての部屋を使って夷現すること を想定して設定された住戸規模が示されている。現行の 住宅統計調査は，この住戸規模と世帯人員の単純な相対 関係だけで最低居住水準未満世帯数を算出しているが, この方法では住戸規模設定の根拠となった住まい方が実 際に行われているか否かの詳細が不鮮明である。さらに，
小規模住宅において公私室型の住まい方にも，住戸を個 室で区切ることに対する問題点が指摘されて(いる文4)7)。

本報告では，最低居住水準に規定された住まい方の基 準則を指標として, 公共賃貸住宅の住まい方の実態分析 を行い，その住まい方と最低居住水準の住まい方の基準 則（以下基準則と略す）に想定された住まい方との乘離 の実態とその要因を明らかにすることを目的とする。

\section{2. 分析の資料・方法}

使用した資料は，福岡県内の都市部に立地する公共貨 貸住宅 49 団地 (県営 14 団地, 市営 19 団地, 公団 9 団地, 公社 7 団地; 表一 1 参照) を対象とした留置アンケート 調查である（1980 年 8 月実施，有効回収調查票数 4696

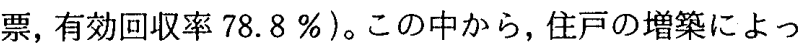
て呼称住宅型と実際の住宅型が一致しないケースは住宅 型を修正した後すべての住宅型にういて，基準則に関 する調查項目に回答のあった調査票（3558 票）を抽出 した (永2)。ここで，食寝分離・就寝分離を基にした基準

\footnotetext{
本報は関連発表論文 1)，2）の内容を基に再分析し，加筆再編し，まとめたものである。

* 徳山工業高等専門学校士木建築工学科 助手・工修

** 九州大学工学部建築学科 教授. 工博

*** 山口大学工学部社会建設工学科 助教授・工博 Tokuyama College of Technology, M. Eng. Prof., Dept. of Architecture Faculty of Engineering, Kyusyu Univ., Dr. Eng.

Assoc. Prof., Dept. of Civil Engineering Faculty of Engineering, Yamaguchi Univ., Dr. Eng.
} 


\section{表一1 調查対象公共貸貸住宅の建設時期と住宅型別戸数}

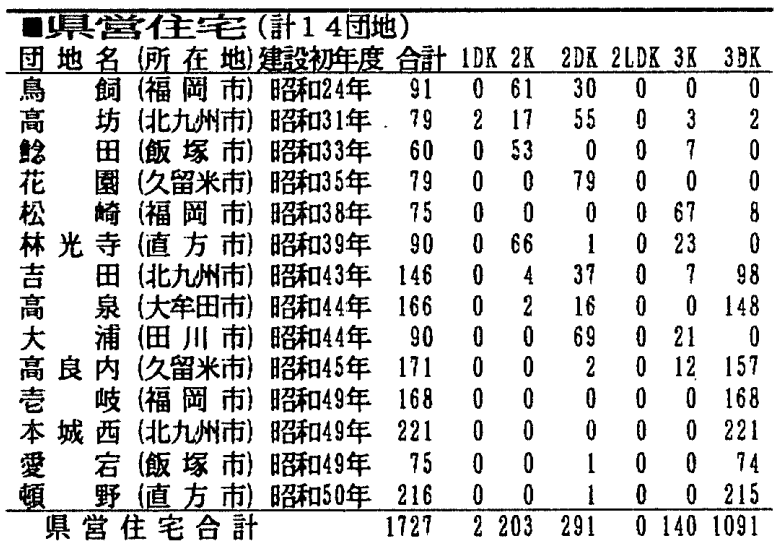

面管住它(許19団地)

団地名(所在地)建設初年度 合計 IDK 2R 2DK 2LDR 3K $30 \mathrm{R}$

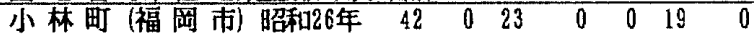

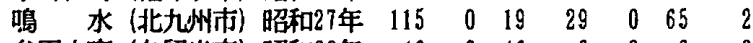

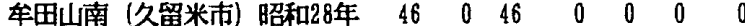

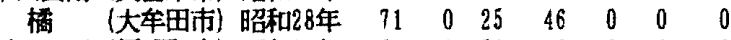

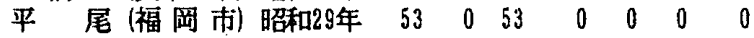
旭 町 (久留米市) 昭和32年 $30 \begin{array}{lllllll}30 & 0 & 30 & 0 & 0 & 0 & 0\end{array}$

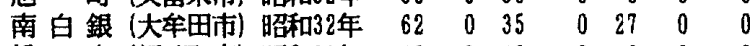
松 本 (飯 塚 市) 昭和33年 48 o 永犬丸西町(北九州市) 昭和38年 $65 \begin{array}{lllllll}65 & 0 & 2 & 63 & 0 & 0 & 0\end{array}$

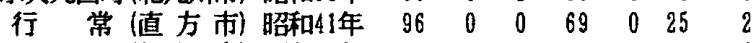

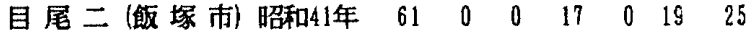

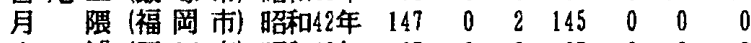

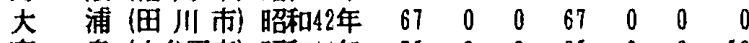

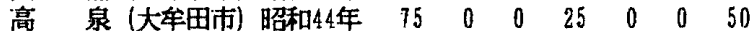

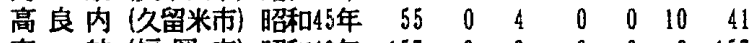

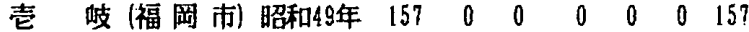
本城 西 (北九州市) 昭和49年 235 年

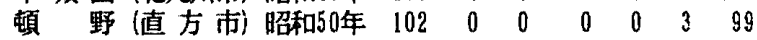
西个浦 (田川市) 昭和52年 70 年 市営住宅合計

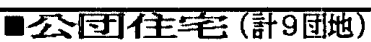

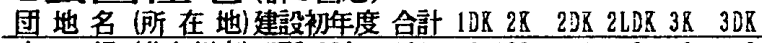
白 銀 (北九州市) 昭和30年 $101 \quad 0 \begin{array}{llllll}100 & 1 & 0 & 0 & 0\end{array}$ 別府 (福岡市) 昭和34年 $\begin{array}{llllllll}93 & 26 & 0 & 46 & 0 & 16 & 5\end{array}$ 大門一丁目(北九州市) 昭和35年 $70 \begin{array}{lllllll}70 & 29 & 4 & 37 & 0 & 0 & 0\end{array}$ 黒 原 (北九州市) 昭和41年 85 35 大名第二 (福 岡 市) 昭和42年 $97 \begin{array}{lllllll}46 & 0 & 46 & 0 & 0 & 5\end{array}$

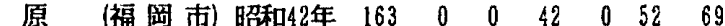

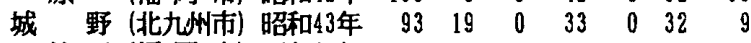

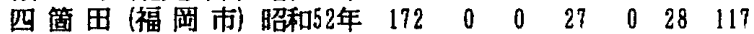
本城西 (北九州市) 昭和52年 102 年 $\begin{array}{llllllll}\text { 公団住宅合計 } & 976 & 155 & 104 & 282 & 0 & 128 & 307\end{array}$

立社住宅(評7団地)

団地名 (所在地) 建役初任度 合計 $1 D R 2 R \quad 2 D R$ 2LDR $3 R \quad 3 D R$

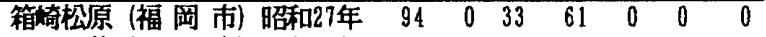

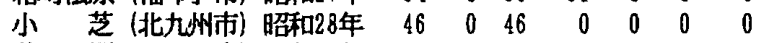

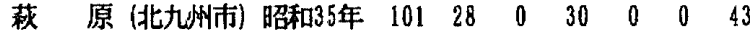
名島(福 岡市) 昭和43年 $109 \quad 0 \quad 0069000040$

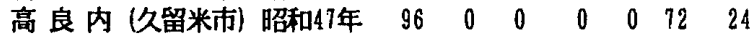

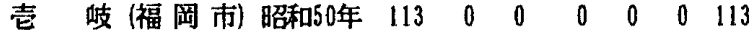
本城西 (北九州市) 昭和51年 110 0 $\begin{array}{llllllll}\text { 公社住宅合計 } & 669 & 28 & 79 & 160 & 0 & 72 & 330\end{array}$

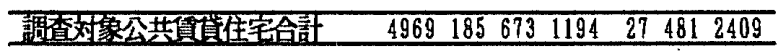

則の適合判別に乗りにくい単身世帯 $(176$ 票) ・ 久損家 族 (258 票) •夫婦別室就寝の世帯 (477 票) を分析から 割愛して 2647 票とした注3)。さらに，居住水準判定が自 明である $1 \mathrm{DK}$ の 2 人以上世帯 (59 票) と $2 \mathrm{~K} ・ 2 \mathrm{DK}$ ・ $3 \mathrm{~K}$ の 5 人以上世帯 $(81$ 票), $3 \mathrm{DK}$ の 6 人以上世帯 (21 票)，およびサンプル数の少ない住宅型の $2 \mathrm{LDK}$ $(5$ 票) 3 LDK ( 2 票) 4 K (1 票) を分析から割愛す
表一2 分析対象資料の住宅型および世帯人員別世帯数

\begin{tabular}{|c|c|c|c|c|c|}
\hline 焦宝型 & $2 \mathrm{~K}$ & $2 \mathrm{DK}$ & $3 \mathrm{~K}$ & $3 \mathrm{D} \mathrm{K}$ & 計 \\
\hline 2 人 & $\begin{array}{r}71 \\
(30.9)\end{array}$ & $\begin{array}{r}109 \\
(22.2)\end{array}$ & $\begin{array}{r}30 \\
(15.2)\end{array}$ & $\begin{array}{rrr}2 & 3 & 1 \\
(14.8)\end{array}$ & $\begin{array}{r}4441 \\
(17.8)\end{array}$ \\
\hline 3 人 & $\begin{array}{r}67 \\
(28.1)\end{array}$ & $\begin{array}{r}139 \\
(28.3)\end{array}$ & $\begin{array}{r}59 \\
(29.8)\end{array}$ & $\begin{array}{r}437 \\
(28.0)\end{array}$ & $\begin{array}{r}702 \\
(28.3)\end{array}$ \\
\hline 4 人 & $\begin{array}{r}92 \\
(40.0)\end{array}$ & $\begin{array}{r}244 \\
(49,6)\end{array}$ & $\begin{array}{l}109 \\
(55.1)\end{array}$ & $\begin{array}{r}715 \\
(45.9)\end{array}$ & $\begin{array}{r}11660 \\
(46,8)\end{array}$ \\
\hline 5 人 & - & - & - & $\begin{array}{l}175 \\
(11.2)\end{array}$ & $\begin{array}{r}175 \\
\left(\begin{array}{l}7 \\
7\end{array}\right)\end{array}$ \\
\hline 計 & $\begin{array}{c}230 \\
(100.0)\end{array}$ & $\begin{array}{r}492 \\
(100.0)\end{array}$ & $\begin{array}{r}198 \\
(100.0)\end{array}$ & $\begin{array}{r}1558 \\
(100.0)\end{array}$ & $\begin{array}{r}2478 \\
(100.0)\end{array}$ \\
\hline
\end{tabular}

単位：世帯，1 内内\%
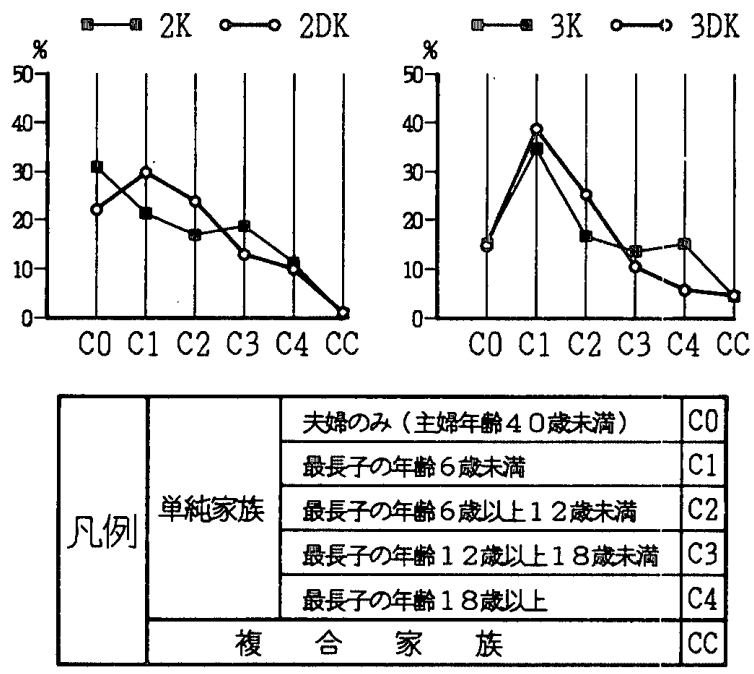

図一1 分析対象資料の家族型構成

ると，分析対象は表一2のように 2478 票となった。

この分析対象世帯の家族型構成を住宅型別に図一1に 示す。これをみると， $3 \mathrm{~K} \cdot 3 \mathrm{DK}$ では，最長子の年㱓 6 歳未満の単純家族が最も多く,それぞれ $34.8 \%$. $38.8 \%$ を占める。同様に $2 \mathrm{DK}$ でも，この家族型が $29.9 \%$ で最も多いが, $2 \mathrm{~K}$ では主婦年齢 40 歳未満の夫 婦のみの世帯が $30.9 \%$ で最も多く，各住宅型とも子供 の年齢の低い比較的若い世帯が多いのが特徵である。

分析はアンケートに記入された住まい方の実態につい て，最低居住水準の住まい方の基準則に適合しているか 否かを 1 ケースごとに判別し，その適合率および適合し ない場合の要因の比率を求めた。

\section{3. 最低居住水準の住まい方の基準則と実際の住まいす}

\section{1 基準則と実際の住まい方の乘離}

基準則の内容を要約すると, 2 人以上の世帯について, いわゆる食寝分離を確保すること, 就寝については 6 歳 以上の子供に夫婦と別の寝室を，18 歳以上の者には個 室を確保し，また 12 歳以上の子供は性別就寝とすると 規定されている。この条件を満たす住戸規模が，第 3 期 住宅建設 5 力年計画以来, 世帯人員に応じて設定されて 
おり，2～5 人世帯については図-2 のように定められて きた。

しかし実際の住まい方では，この想定よ゙おりに全室を 使って就寝することは少なく，親子が 1 室に集中就寝す る事例が数多く報告されている㸚)-11)。これは最低居住 水準を満足する世帯人員と住戸規模であっても就寝に用 いない部屋（非就寝室）を確保していることを示してお り，居間.・接客室・納戸あるいは余室として使われてい る。

このような住まい方をした場合，住宅規模に関する最 低居住水準を達成していても，実際の住まい方からみる と就寝形態が基準則に適合せず，乘離現象が生ずる。

\section{2 最低居住水準達成率と基準則適合率}

昭和 58 年の住宅統計調査によると, 全国の最低居住 水準達成率は, 公営の借家; $64.7 \%$, 公団・公社の借家 ; $72.2 \%$ で，平均 $66.9 \%$ となっている。また調査対象 地域の福岡県における最低居住水準達成率は, 公営の借 家; $70.5 \%$, 公団・公社の借家; $79.7 \%$ で, 平均 73.7 \%である注4。これは，家族構成に応じ必要とされる居 住室の広さ.(畳数) を算出して得た達成率である。この 算出方法で本報の分析対象世帯の最低居住水準達成率を 求めると, 2 人世帯ならば $1 \mathrm{DK}$ 以上, 3 人世帯では $2 \mathrm{DK}$ 以上, 4 人世帯では3 DK 以上の住宅に 居住する場合は，すべて達成率 100 \%ということになる。しかし 基準則の適合率を求めると；住宅 統計調查上で $100 \%$ の達成率が 得られる世帯人員と住宅規模の関 係においても，基準則適合率はか なり低く，2人世帯では $2 \mathrm{~K}$; $35.2 \%, 2 \mathrm{DK} ; 49.5 \%, 3 \mathrm{~K}$; $53.3 \%$ ，3DK ; $63.6 \%$ であり， 3 人世帯で標準的な $2 \mathrm{DK} て ゙ も$ $50.4 \%$ で，3K では $59.3 \% ， 3$ DK で.は $64.5 \%$ の適合率にとよ゙ まっている。最も標準的世帯と考 えられている 3 DK 4 人世帯にお いても, 適合率は $20.3 \%$ と極端 に低い。また, 3 DK 5 人世帯で. の適合率は $10.3 \%$ である。

一方，住宅統計調査上は最低居 住水準を満たさない $2 \mathrm{~K} 3$ 人世帯 で $16.4 \%, 2 \mathrm{DK} 4$ 人世帯で 9.8 $\%, 3 \mathrm{~K} 4$ 人世帯で $2.8 \%$ の世帯 が基準則に適合しているという逆 の現象もみられる。(図一-3参照)

\section{3 非就寝室の確保}

住宅規模が最低居住水準未満である場合, 全室就寝し ても基準則に適合できない割合（図一 3 における「不適 合 FR」率）が高くなる。これに相当するものは， $2 \mathrm{~K}$

\begin{tabular}{|c|c|c|}
\hline $2 人$ & (1)主蒋室 & D K \\
\hline 1DK (10．5畳) & C (6胃) & (4.5县) \\
\hline
\end{tabular}

\begin{tabular}{|c|c|c|c|}
\hline 3 人 & (1)主寝室 & (2)副寝室 & D K \\
\hline 2DK (15，0量) & $\mathrm{C}$ (6量) & P (4，5畳) & (4，5畕) \\
\hline
\end{tabular}

\begin{tabular}{|c|c|c|c|c|}
\hline 4 人 & (1)主寝室 & (2)副寝室 & (3)副寝室 & DK \\
\hline 3DR (19，5異) & C (6嘼) & P (4，5量) & P (4，5量) & (4.5畳) \\
\hline
\end{tabular}

\begin{tabular}{|c|c|c|c|c|}
\hline 5 人 & (1)主寝室 & (2)副寝室 & (3)副寝室 & D K \\
\hline 3DR (22.5畳) & C（6嘼) & $P \cdot P$ (6量) & $\mathrm{P}(4$ ，5賁 $)$ & (6畳) \\
\hline
\end{tabular}

凡 例

世带人員

住宅型 (圆数)

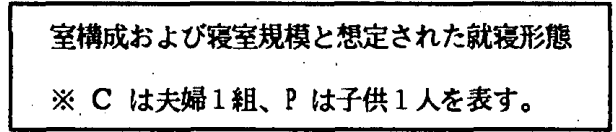

図一2 最低居住水準の住宅規模

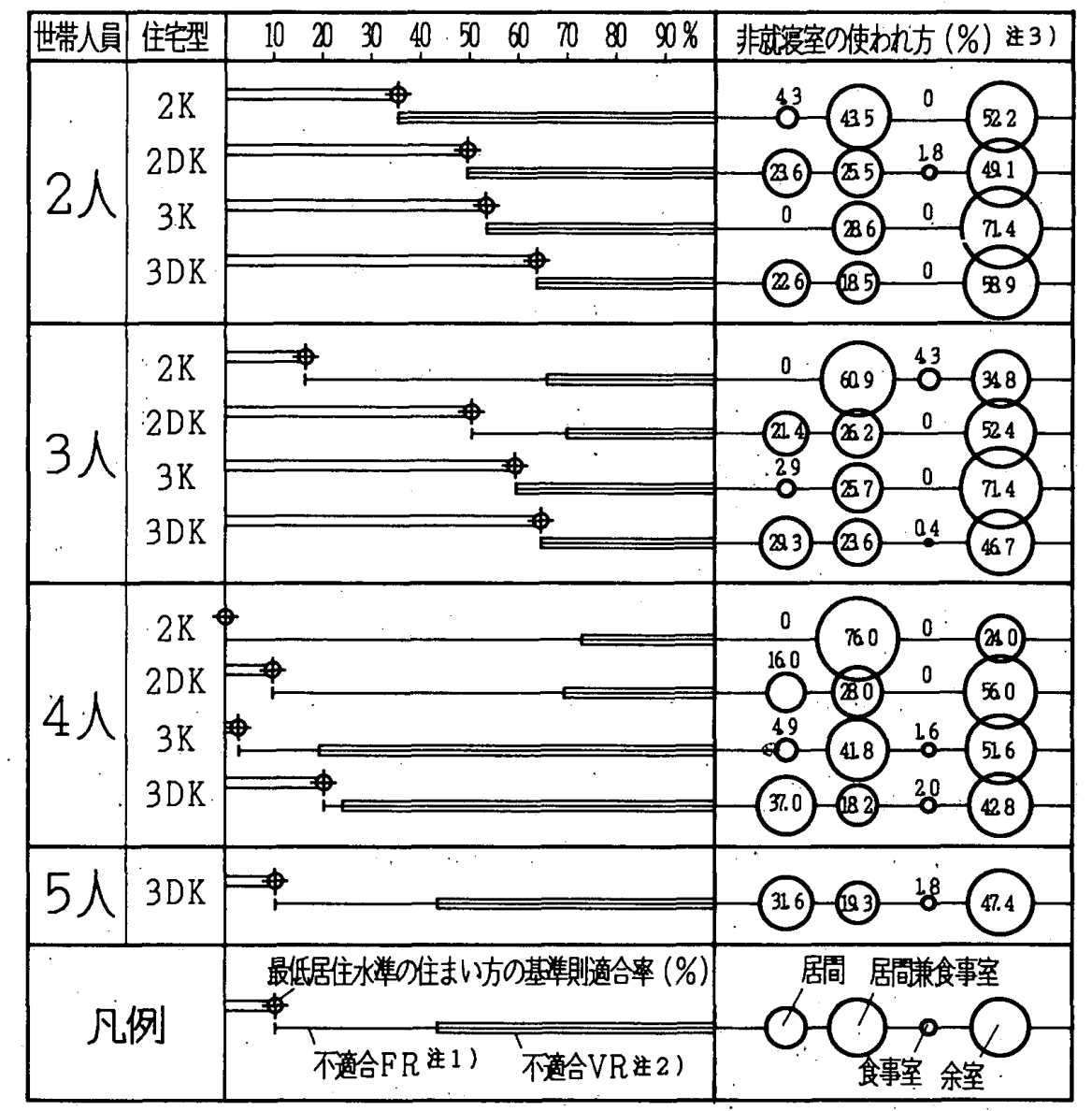

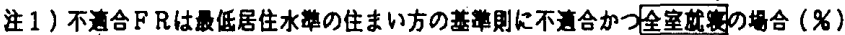

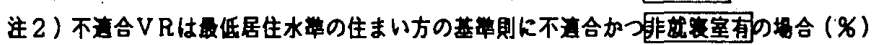

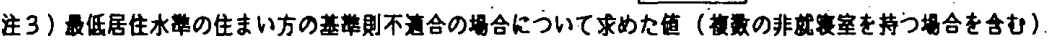

図一3 最低居住水準の住まい方の基準則適合率と非就蔓室使われ方 
3 人世帯の $49.3 \%, 2 \mathrm{~K} 4$ 人世帯の $72.8 \%, 2 \mathrm{DK} 4$ 人 世帯の $59.4 \%, 3 \mathrm{~K} 4$ 人世帯の $16.5 \%$ である。また 3 DK 5 人世帯においては $33.1 \%$ が全室就寝しても基準 則に適合していない。

基準則に適合しない世帯の中で非就寝室を持つ世帯に

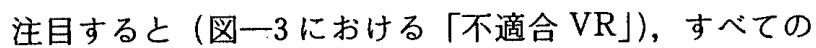
居室を就寝室とすれば最低居住水準を達成できる場合に おいても，非就寝室を確保しており，3人世帯では 2 DK の $30.2 \%, 4$ 人世帯では $3 \mathrm{DK}$ の $75.9 \%$ がこれに 当たる。 4 人世帯の $2 \mathrm{~K}$ や $2 \mathrm{DK}$ では世帯人員と住宅規 模の関係から就寝条件が敩しいにもかかわらず，それぞ れ $27.2 \%, 30.7 \%$ が非就寝室を確保している。4人世 帯の中でも特に $3 \mathrm{~K}$ では $80.7 \%$ に非就寝室があり，3 DK 5 人世帯についても全室就寝しなければ基準則に適 合できないが，実際は $56.6 \%$ が非就寝室を確保してい る。これは全室就寝して基準則に適合させることよりも， 非就寝室の確保が優先されている結果である。

この非就寝室の用途は, $2 \mathrm{~K}$ や $3 \mathrm{~K}$ などのダイニング キッチンのない住宅型では居間兼食事室として使われる 場合が多く, $2 \mathrm{DK} \cdot 3 \mathrm{DK}$ では居間の場合と居間兼食事 室の場合がみられ，世帯人員が増えるにつれて居間の占 める割合が高くなる。世帯人員が住宅規模に対して少な い場合は，普段は使用しない余室としている傾向が強い (図一 3 参照)。

\section{4. 最低居住水準の住まい方の基準則不適合要因}

4.1 住まい方の基準則不適合要因の分類の考え方

最低居住水準の住まい方の基準則に不適合である要因 を明確にするために，世帯人員と住宅型および主寝室の 就漫人数によって不適合要因を分類した上で詳細に分析 する必要がある。実際の住まい方を考えると基準則が不 適合となる判別基準は以下の 8 種類となる。

$\mathrm{A} ：$ 食寝分離ができていない。

$B$ ：主寝室規模が 6 畳未満である。

$C ：$ 主寝室に 6 歳以上の子供が就寝している。

$\mathrm{D}$ ：主寝室に子供が 2 人以上就寝している。

$\mathrm{E} ：$ 複数就寝の副寝室規模が 6 畳未満である。

$\mathrm{F}$ ：複数就寝の副寝室に個室を確保すべき 18 歳以上 の者が就寝している。

$\mathrm{G}$ ：性別就寝すべき子供が異性と同一副寝室で就寝し ている。

$\mathrm{H}$ ：副寝室に子供が 3 人以上就寝している。

また，この分析では主寝室以外の部屋に子供が何人就 寝するか，そして副寝室がいくつあるかで基準則適合の 判別条件が異なってくる。これを考慮して，世带人員と 住宅型がどの組合せであっても判別条件が共通になるよ うに就寝形態を以下の 4 つのケースに分類した。

CASE 1：全員が主寝室に集中就寝する場合。居室が
2 室以上ある住戸では必ず非就寝室が生じ る。

CASE 2：主寝室以外の部屋に子供 1 人が就葠する場 合。3人以上の世帯で起こるケース。主寝空 には夫婦のほかに 4 人世帯の場合子供 1 人, 5 人世帯では子供 2 人が就寝する。

CASE 3 : 主寝室以外の部屋に子供 2 人が就寝する場 合。4人以上の世帯で起こるケース。副寝室 が 2 部屋以上ある場合は, 子供 1 人ずつが 別々の部屋で就寝する場合と 2 人が同じ部屋 に就寝する場合とが考えられる。主寝室には 4 人世帯の場合夫婦のみ, 5 人世帯では夫婦 と子供 1 人が就寝する。

CASE 4 : 主寝室以外の部屋に子供 3 人が就寝する場 合。 5 人以上の世帯で起こるケース。部屋数 が增えるに従い副寝室の数と子供の人数の組 合せによって住み方のパターンが多数考えら れる。

以上のケースによる分類を行い，住宅型と世帯人員に よって生じる組合せを整理し，世帯人員が何人であるか を軸に以下の分析を進める。

\subsection{2 人世帯 $\cdot 3$ 人世帯の基準則不適合要因}

まず，2人世帯の場合の適合率と不適合要因の比率の 関係を図一 4 に示す。 2 人世帯の場合は，全住宅型で主 寝室以外に非就寝室が物理的に確保できているにもかか わらず基準則不適合の場合がある。これは主寝室規模が 基準に満たないためで, $2 \mathrm{~K} て ゙ ~ 32.4 \%, 2 \mathrm{DK}$ で $40.4 \%$, $3 \mathrm{~K}$ で $26.7 \%$ ，3DK で $33.8 \%$ がこれに当たる。これ は団らんや接客の用途に広い部屋を確保し，狭い方の部 屋を主寝室としていることが要因と考えられる。また DK がない住宅型では食寝分離ができていない世帯の割 合が $2 \mathrm{~K}$ で $36.6 \%, 3 \mathrm{~K}$ で $20.0 \%$ と $2 \mathrm{DK}$ の $14.7 \%$, $3 \mathrm{DK}$ の $3.5 \%$ と比較して高い。

次に，3 人世帯について基準則不適合要因比率を求め たのものが図一5である。3人が主寝室に集中就蔓する CASE 1 では主寝室に夫婦と共に就寝している子供の年 齿合が 6 歳以上の場合が不適合要因に加わる。しかしる人 世帯の適合率は $2 \mathrm{~K}$ で $32.4 \%, 2 \mathrm{DK}$ で $48.1 \%$ とえ人 世帯の場合 $(2 \mathrm{~K} ; 35.2 \%$ ，2DK $49.5 \%)$ をやや下回 るにすぎないが， $3 \mathrm{~K} \cdot 3 \mathrm{DK}$ では，それぞれ $70.3 \%$ • $69.4 \%$ とかなり高い適合率を示している。

CASE 2 は副寝室に子供 1 人が就寝することから，2 K では必然的に食寝分離が $100 \%$ 行われておらず， $3 \mathrm{~K}$ においても $45.5 \%$ の世帯で食寝分離が行われていな い。2 DK では食寝分離が行われていない世帯が 25.9 $\%$ ，主寝室規模が 6 畳未満である世帯が $25.91 \%$ と不適 合要因比率に差がなく，3DKでは $42.5 \%$ の世帯で主 寝室規模が基準に満たず不適合要因の大半吉占めてい 


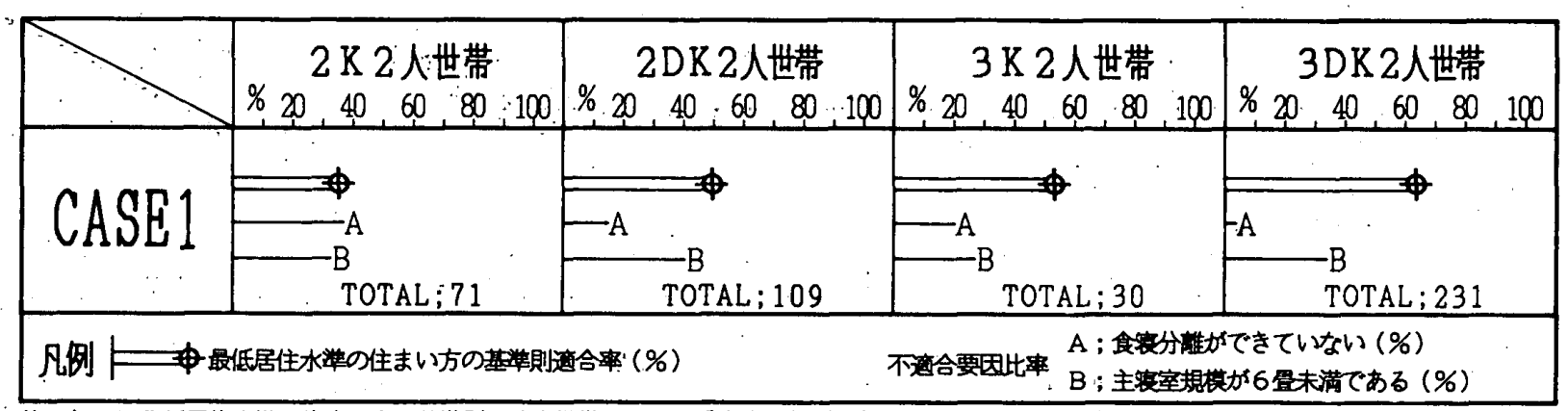

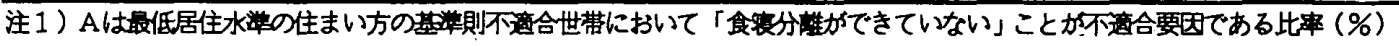

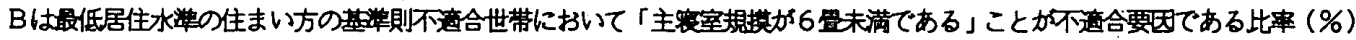

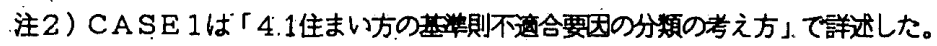

図一4 2 人世帯における最低居住水準の住まい方の基準則不適合要因比率

\begin{tabular}{|c|c|c|c|c|}
\hline & $\begin{array}{c}2 \mathrm{~K} 3 \text { 3世世带 } \\
\% 20,40,60,80,100 \\
\end{array}$ & $\begin{array}{c}\text { 2DK3人世带 } \\
\% 20: 40 \quad 60 \quad 80,100 \\
\end{array}$ & 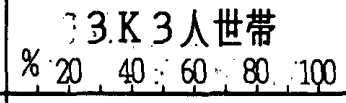 & $\begin{array}{c}3 D K 3 \text { 人世带 } \\
\% \approx 0,40,60,80,100 \\
\end{array}$ \\
\hline CASE 1 & \begin{tabular}{|c|} 
\\
$\mathrm{A}$ \\
$\mathrm{C}$ \\
\\
T.OTAL; 34 \\
\end{tabular} & \begin{tabular}{|ll}
$\mathrm{A}$ & \\
$\mathrm{B}$ & $\mathrm{B}$ \\
& $\mathrm{C}$ \\
& TOTAL;81 \\
\end{tabular} & \begin{tabular}{|l}
$-A$ \\
$-B$ \\
$-C \quad$ TOTAL;37 \\
\end{tabular} & \begin{tabular}{|l}
$-\frac{}{-A}$ \\
$-C$
\end{tabular} \\
\hline CASE2 & \begin{tabular}{|ll} 
B & \\
& TOTAL: 33 \\
\end{tabular} & \begin{tabular}{|l}
\multicolumn{1}{|c}{} \\
$\mathrm{A}$ \\
$\mathrm{B}$ \\
TOTAL; 58 \\
\end{tabular} & \begin{tabular}{|l}
${ }^{\circ}$ \\
B \\
TOTAL;22 \\
\end{tabular} & 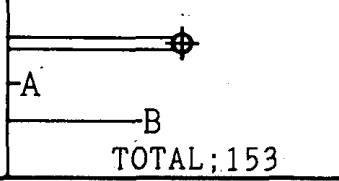 \\
\hline 侣 & 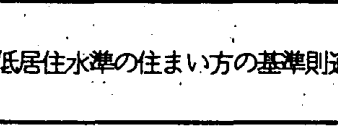 & - & 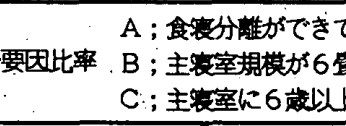 & 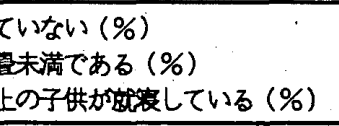 \\
\hline
\end{tabular}

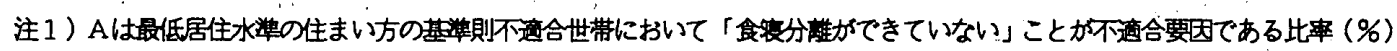

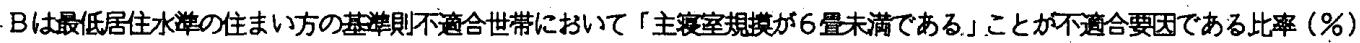

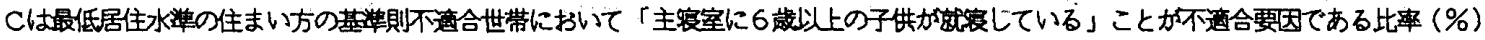

注2 ) CASE1，CASE2は「4.1住まい方の則不道合要因の分類の考え方」で詳述した。

図一5 3 人世帯における最低居住水準の住まい方の基準則不適合要因比率

る。

4.34 人世帯 $\cdot 5$ 人世帯の基準則不適合要因

4 人世帯については 4.1 で示したように就謾形態を 3 通りのケースに分類し, $3 \mathrm{DK} 5$ 人世帯の場合は 4 通 りに分類した（図一6参照）。

CASE 1 は全員が主寝室に集中就葠している場合で, 主寝室に子供が 2 人以上就寝することになり，すべての 世帯が基準則不適合である。食寝分離が行われていない ことが不適合要因となる比率は. $2 \mathrm{~K}$ で $24.0 \%, 3 \mathrm{~K}$ で $11.8 \%$ で, DKのある場合 $(2 \mathrm{DK} ; 8.0 \%, 3 \mathrm{DK} 4$ 人； $1.8 \%, 3 \mathrm{DK} 5$ 人；0.0\%）と比較すると高い値を示す。 しかし.部屋数の関係を考慮するとCASE 2 やCASE 3 に比較して食寝分離が不適合要因になる比率は低く，4 人が集中就寝することによって食寝分離を優先させた場 合と考えられる。ところが集中就寝している主寝室が 6 畳末満である場合が $2 \mathrm{~K} ; 32.0 \%, 2 \mathrm{DK} ; 33.3 \%, 3 \mathrm{~K}$; $26: 5 \%, 3 \mathrm{DK} 4$ 人; $22.8 \%, 3 \mathrm{DK} 5$ 人; $20.0 \%$ と多数 みられる。また 3 DK 5 人世帯では主寝室に 6 歳以上の
子供が就寝している比率が $80.0 \%$ と非常に高く, $2 \mathrm{~K}$ 4 人世帯でも $56.0 \%$ を示し, 子供の年秢が高くなって も分離就寝が行われていない状況を表している。

子供 1 人が別室に就寝するCASE 2 では, 部屋数の 関係から専用の食事室がとれない場合が $2 \mathrm{~K}$ で生じ， 全世帯が最低居住水準の住まい方の基準則に適合してい ない。また $2 \mathrm{DK}$ の $36.4 \%, 3 \mathrm{~K}$ の $50.0 \%$ も食寝分離 が行われていない。主寝室規模が 6 畳未満であることも 不適合要因の 3 4 割を占め，また規模の小さい住宅で は主寝室に就寝する子供の年秢が 6 . 歳以上の場合が多 く, $2 \mathrm{~K}$ では $77.3 \%, 2 \mathrm{DK}$ では $50.0 \%, 3 \mathrm{~K}$ では $56.3 \%$ である。同じ不適合要因が $3 \mathrm{DK} 4$ 人世帯では $28.8 \%, 3 \mathrm{DK} 5$ 人世帯では $10.0 \%$ にすぎない。しかし， $2 \mathrm{DK}$ では $18.2 \% ， 3 \mathrm{~K} て ゙ は 18.8 \%, 3 \mathrm{DK}$ では 29.7 \% が最低居住水準に実質的に適合しており，非就寝室 と食事室を確保した上で最適居住水準の想定した住まい 方に適合した世帯（主寝室に夫婦と6 歳未満の子供 1 人 が就寝し, 副寝室にもう 1 人の子供が就寝する世帯）が 


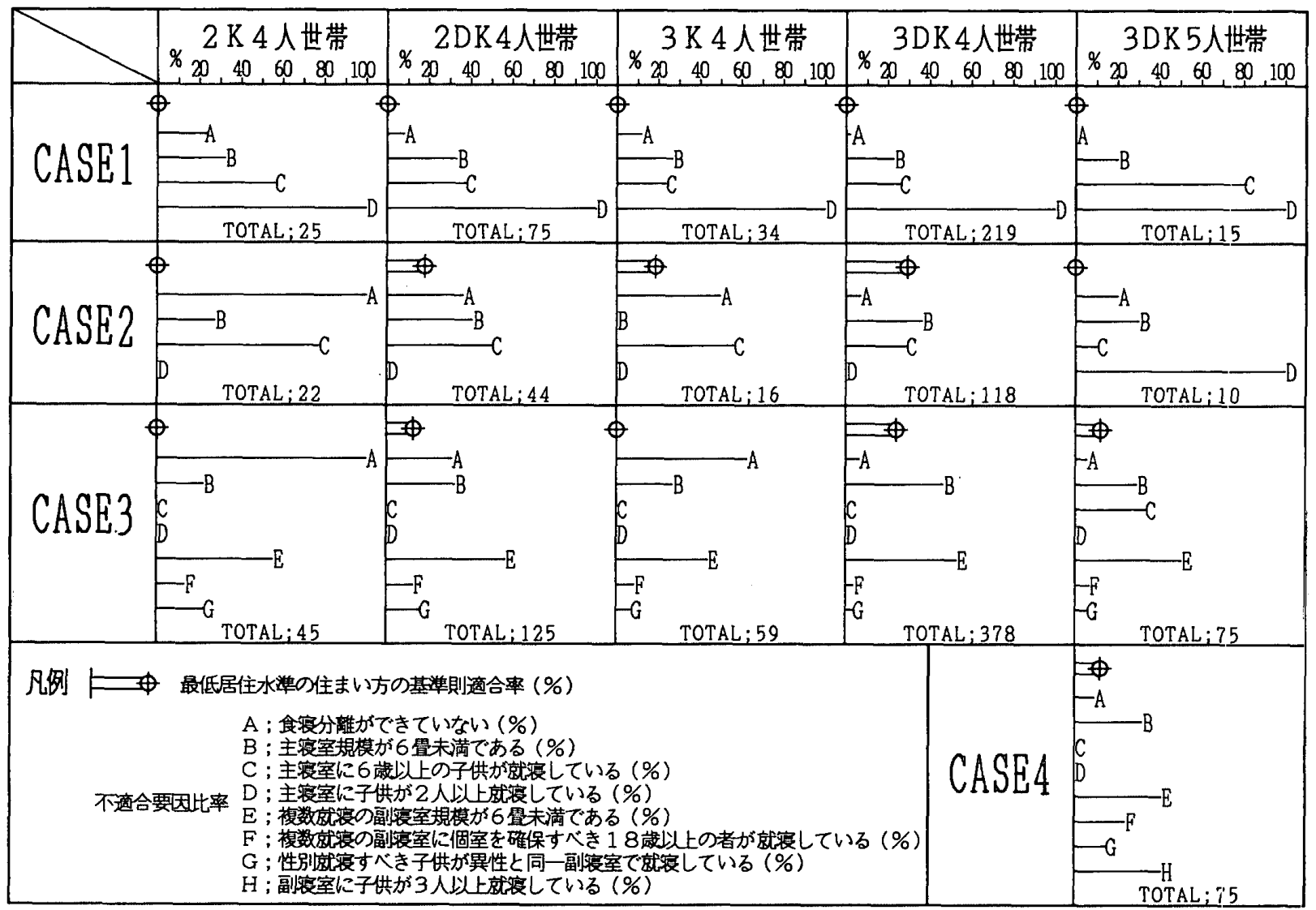

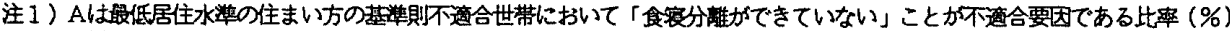

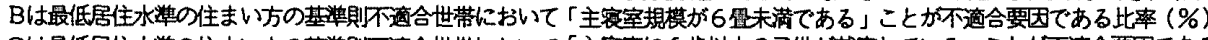

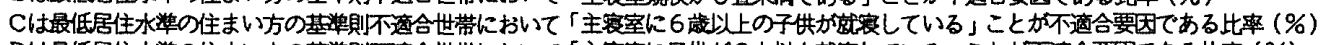

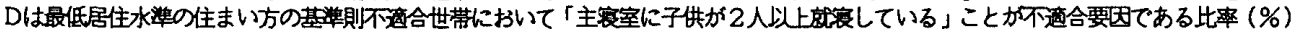

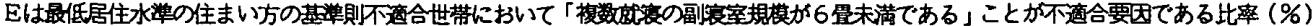

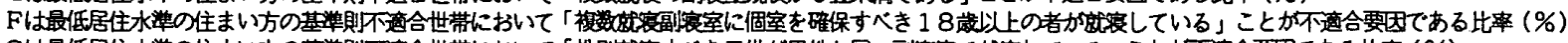

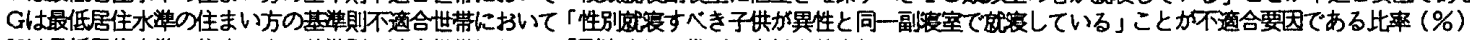

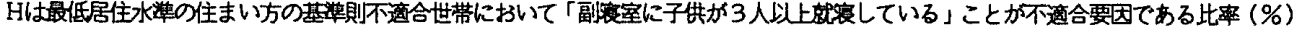

注2) CASE 1，CASE 2,CASE 3，CASE4は「4.1 住まい方の㥍則不適合要因の分類の考え方」で詳述した。

图一6 4 人世帯・ 5 人世帯における最低居住水準の住まい方の基準則不適合要因比率

この割合であることを示している。

CASE 3 ではDK のない住宅型である $2 \mathrm{~K}$ の全世帯, $3 \mathrm{~K}$ の $62.7 \%$ の世帯で食寝分離ができておらず，これ が最低居住水準の住まい方の基準則不適合の第一の要因 である。 $2 \mathrm{~K} ・ 3 \mathrm{~K}$ の第二の不適合要因は複数就寝の副 寝室規模が 6 畳末満であることで， $2 \mathrm{~K}$ は $55.6 \% ， 3 \mathrm{~K}$ は $44.1 \%$ である。この不適合要因は他の住宅型では第 一の不適合要因比率を示し, $2 \mathrm{DK}_{4}$ 人世帯では $56.8 \%$, $3 \mathrm{DK} 4$ 人世帯では $53.2 \%, 3 \mathrm{DK} 5$ 人世帯では $50.7 \%$

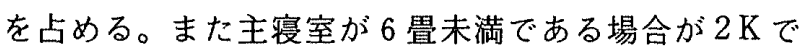
$22.2 \%, 2 \mathrm{DK}$ で $32.8 \%, 3 \mathrm{~K}$ で $27.1 \%, 3 \mathrm{DK} 4$ 人世 帯で $46.8 \%, 3$ DK 5 人世帯で $29.3 \%$ と高い比率を示 している。このように主寝室や複数就蔓の副寝室規模が 水準に満たない場合が多いことは，最も広い部屋を非就 寝室として確保していることによるものである。

ところが副寝室に 2 人の子供が就寝していても，個室 を確保すべき場合や性別就寝で問題のある場合は比較的 少なく, 個室確保が不適合要因となる比率は $2 \mathrm{~K} ; 13.3$ $\%, 2 \mathrm{DK} ; 12.8 \%, 3 \mathrm{~K} ; 8.5 \%, 3 \mathrm{DK} 4$ 人; $3.7 \%, 3$
DK 5 人; $6.7 \%$ で, 性別就寝が不適合要因となる比率 は $2 \mathrm{~K} ; 22.2 \%, 2 \mathrm{DK} ; 16.0 \%, 3 \mathrm{~K} ; 6.8 \%, 3 \mathrm{DK} 4$ 人; $3.4 \%, 3 \mathrm{DK} 5$ 人; $5.3 \%$ にすぎず，複数就寝の副 寝室の規模が要因となって適合率を引き下げている実態 を端的に示している。

\section{5. まとめ}

本報では最低居住水準における住まい方の基準則を指 標として，公共賃貸住宅の住まい方の奏態を分析した。 この基準則と実態の乘離の特徵点は以下のようにまこめ られる。

(1) 住宅統計調查上で最低居住水準を満たしている世帯 において,住まい方の基準則に適合している割合は低く， 2 人世帯では $2 \mathrm{~K} ; 35.2 \%, 2 \mathrm{DK} ; 49.5 \%, 3 \mathrm{~K} ; 53.3 \%$, $3 \mathrm{DK} ; 63.6 \%$ にすぎない。3 人世帯で標準的な $2 \mathrm{DK}$ に おいても適合率は $50.4 \%$ であり， $3 \mathrm{~K}$ では $59.3 \%, 3$ DK では $64.5 \%$ にとどまっている。 4 人世喨で最も標 準的と考えられる $3 \mathrm{DK}$ においては，適合率が $20.3 \%$ と極端に低い。 
(2) 基準則に適合しない主な要因は, 最も広い部屋を非 就寝室に当てることから, 主寝室や複数就寑の副寝室が 6 疊末満となり, 寝室規模が基準則を下回ることにある。 (3) DK の無い住宅型では, 食寝分離ができていない ケースが多数みられる。

(4) 居間兼食事室・居間・余室として非就寝室を確保し ている世帯が多く, 最低居住水準未満世帯においても非 就寝室の確保が就漫分離よりも優先される場合があり, 居間兼食事室・居間・余室の確保要求が強いことが分か る。

(5)狭い寝室での過密就寝が継続し, 子供の年粭や性別 によっては, 親子の分離就寝, 子供の性別就寝, 個室確 保などの面で問題を含んでいる場合が少なくない。

\section{注}

1) 昭和 58 年住宅統計調查による最低居住水準未満世帯は 395 万世帯で, 総世帯数の $11.4 \%$ に当たる。昭和 63 年 住宅統計調查においても最低居住水準末満世帯は依然と して 355 万世帯あり，総世帯数の $9.5 \%$ に及ぶ。

2) この段階で， 3 畳の部屋があるデー夕，6畳を上回る部 屋があるデータおよび DK・LDK を寝室としている世帯 のデータは排除した。この際, 呼称住宅型の住戸に 6 畳 の部屋が 1 室以上あることが最低居住水準以上の住宅型 に対応する条件であるが，2K；251 票の $90.0 \%$ 以上, 2 $\mathrm{DK} ; 522$ 票の $78.7 \%$ 以上, $3 . \mathrm{K}$; 228 票の $96.5 \%$ 以上, $3 \mathrm{DK} ; 1579$ 票の $97.3 \%$ 以上がこれに当たる。ここで対 応関係が決定できないケースがあるが,これは調查票に 示された使われ方以外の目的で使用された非就寝室があ る場合，その規模が不明であることによる。また 3 寝室 型で 6 睤間が 2 室以上であることが確認できている調査 票は, $3 \mathrm{~K}$ で54.8％(125 票), 3DK で36.8％(581票) である。

3）第 3 期住宅建設 5 力年計画における「別紙 1 最低居住 水準」のなかで定めている住戸規模の目標は「標準世帯」 すなわち「4 住戸規模の目標（注）1 標準世帯とは, この場合，夫婦と分離就寝すべき子供より構成される世 帯をいう。」が前提となっている。また, 寝室の条件は 「1 居住室について (1) 寝室は次の条件を满たすもの とする。イ 夫婦の独立の寝室を確保する。ただし，満 5 才以下の子供 (就学前児童) 1 人までは同室も可とす る。とある。これらを根拠として単身世帯・傊家族・ 夫婦別室就寝の世帯を基準則の適合判別の分析対象から 割愛した。

4) 昭和 63 年住宅統計調查による最低居住水準の達成率は, 全国の公営の借家で $71.7 \%$, 公団・公社の借家で 74.8 $\%$, 公共貨貸住宅の平均で $72.6 \%$ とやや改善された。 また福岡県でも公営の借家で $75.5 \%$, 公団・公社の借家 で $80.9 \%$, 公共兵貸住宅の平均で $77.1 \%$ とわすかなが ら改善された。

\section{関連発表論文}

1）青木正夫, 竹下輝和ほか 2 名：公的偊貸住宅における最
低居住水準の見かけの達成率と実質達成率について（そ の 1), (その 2), 日本建築学会大会学術講演梗概集, F巻, pp. $577 \sim 580,1985.10$

2）古田健一：公共貨貸住宅の最低居住水準達成率について, 徳山工業高等専門学校研究紀要, 第 13 号, pp. 129 134, 1989.12

\section{参考文献}

1）鈴木成文, 初見 学：住居における公室の計画に関する 研究, 住宅建築研究所報, No. 8, pp. 119 132, 1982.3

2）笠䳋 泰, 今井正次, 松本壮一郎：ライフサイクルから みた部屋構成（1），（2），日本建築学会大会学術講演梗 概集, E巻, pp. 35〜38, 1985. 10

3）松本壮一郎ほか 3 名：4 LDK 住户における住戸内生活の 変容に関する研究(1)～(2), 日本建築学会大会学術講演梗 概集, E巻, pp. 171 174, 1987.10

4）本間博文ほか 4 名：公営住宅における平面型の評価に関 する研究 その 1 その 3 , 日本建築学会大会学術講演梗 概集, E巻, pp. 91 96, 1986.8

5）志田正男，赤川俊哉，本間博文：公営住宅における平面 型の評価に関する研究 その 4 その 6, 日本建築学会大 会学術講演梗概集, E巻, pp. $165 \sim 170,1987.10$

6）志田正男, 赤川俊哉,. 本間博文：3LDK 型公営住宅の平 面構成之住み方比較, 日本建築学会大会学術講演梗概集, E巻, pp. $227 \sim 228,1988.10$

7）本間博文：公営住宅の平面型の評価に関する研究 7一開 放型平面型の検討一，日本建築学会大会学術講演梗概集, E巻, pp. 305 306, 1990. 10

8）松本壮一郎ほか 3 名：ライフステージ・平面型と就寝分 離時期・寝室位置一南面 3 室型 $3 \mathrm{LDK}$ 住戸の場合一, 日 本建築学会大会学術講演梗概集, E巻, pp. 221 222, 1988.10

9）青木正夫, 江上 徹, 船越正啓: 公営集合住宅での新し い試みに関するリヴィジット調査 その 1，その 2, 日本 建築学会大会学術講演梗概集, E 巻, pp. 205 208, 1989. 10

10）長山洋子, 沢田知子, 服部岑生：ファミリー・ステージ と居室の使い分け（都営住宅における住まい方の特街と 標準設計の新しいあり方一1), 日本建築学会大会学術講 演梗概集， E巻, pp. 157 158, 1987. 10

11）增田達男ほか 3 名：石川県営住宅にけおる居住状況に関 する考察・その 2 一住まい方状況等について一, 日本建 築学会大会学術講演梗概集, E 巻, pp. 641～642, 1989.10

12）樋口栄作：住要求のヒエラルキー構造における接客室要 求の位置, 日本建築学会計画系論文報告集, No. 400 , pp. $43 \sim 50,1989.6$

13）田中 勝ほか 2 名：居住者の住宅評価による現行居住水 準の再検討, 日本建築学会計画系論文報告集, 第 385 号, pp. $76 \sim 87,1988.3$

14）住宅政策研究会：新たな住宅ビジョン;その施策と展開, 住宅新報社, 1986.9

(1990 年 7 月 9 日原稿受理, 1991 年 4 月 16 日採用決定) 